\title{
STEM etkinliklerinin okul öncesi öğrencilerinin yaratıcı düşünmesine etkisi
}

\section{The effect of STEM activities on creative thinking of preschool students}

\section{Makale Geçmişi \\ Geliş : 4 Ağustos 2020 \\ Düzeltme : 15 Nisan 2021 \\ Kabul : 16 May1s 2021}

\section{Makale Türü}

Araștırma Makalesi

\author{
Sinem Güldemir ${ }^{1}$, Sinan Çınar ${ }^{2}$
}

Öz: Bu çalışmanın amacı, okul öncesi eğitimi 5-6 yaş grubu öğrencilerine yönelik mühendislik tasarıma dayalı STEM etkinlikleri geliştirmek ve bu STEM etkinliklerinin öğrencilerin yaratıcı düşünmesine etkisini tespit etmektir. Araştırmada yöntem yarı deneysel desen benimsenmiştir. Araştırmanın çalışma grubunu, 5-6 yaş grubu sınıflarında öğrenim gören deney grubu ve kontrol grubu olmak üzere toplam 60 ögrenci oluşturmaktadır. Çalışmada 6 STEM etkinliği geliştirilmiş, her bir etkinlik toplam 8 haftalık süreçte uygulanmıştır. Araştırmada Torrance Yaratıcı Düşünme Testi Şekilsel Form A ve B ve saha notları veri toplama aracı olarak kullanılmıștır. Elde edilen bulgulara göre, STEM etkinliklerinin okul öncesi 5-6 yaş grubu çocukların yaratıcılık düzeyleri; orijinallik, akıcılık, zenginleştirme, başlıkların soyutluluğu ve erken kapamaya direnç boyutlarında anlamlı derecede arttırdığı saptanmıştır.

Anahtar Kelimeler: STEM Rehber Materyali, Mühendislik Tasarım Süreci, Yaratıcı Düşünme

Abstract: The aim of this study is to develop STEM activities based on engineering design for preschool education 5-6 age group students and to determine the effect of these STEM activities on students' creative thinking. In the research, the method is adopted semi-experimental pattern. The study group of the research consists of 60 students in the 5-6 age group, the experimental group and the control group. In the study, 6 STEM activities were developed, and each activity was applied in a total of 8 weeks. In the research, Torrance Creative Thinking Test Figural Forms A and B and field notes were used as data collection tools. According to the findings, the creativity levels of children of 5-6 years of preschool age in STEM activities; It was determined that it significantly increased the originality, fluency, enrichment, abstraction of the heads and resistance to early closure.

Keywords: STEM Guide Material, Engineering Design Process, Creativity Thinking

DOI: 10.24130 /eccd-jecs.1967202152295

*Bu çalışma, birinci yazarın yüksek lisans tez çalışmasının bir bölümünden üretilmiştir.

${ }^{1}$ Recep Tayyip Erdoğan Üniversitesi, Eğitim Fakültesi, Fen Bilgisi Öğretmenliği sinem_guldemir15@erdogan.edu.tr,ORCID:

https://orcid.org/0000-0002-0020-1238

${ }^{2}$ Recep Tayyip Erdoğan Üniversitesi, Eğitim Fakültesi, Temel Eğitim Bölümü Okul Öncesi Eğitimi Ana Bilim Dalı, sinan.cinar@erdogan.edu.tr, ORCID: http://orcid.org/0000-0002-5208-8986 


\section{SUMMARY}

\section{Introduction}

Creativity is an inherent feature in children. The talent that we call creativity is the adaptive and motivating element of change, innovation in children. It is also a skill used to analyze and interpret the problems that daily life poses to us. Today, it is accepted as an important goal to develop the creativity of individuals starting from childhood in order to solve various problem situations in the environment, which is getting more and more complicated (The Ministry of National Education [MoNE] 2013). The child should be given the opportunity to perceive, observe and evaluate their environment. The most important factor to reveal and develop this ability is pre-school education level (MoNE, 2019). Preschool education is the period when children gain the most speed in their development areas. Creativity is particularly emphasized in the preschool curriculum. It is known that preschool education offers environments that offer stimulating educational environments, direct children to research and positively affect their creativity (Atay, 2009). Çalışandemir and Bayhan (2011) stated that preschoolers develop their thinking system by offering them a rich stimulating environment and learning environments doing. In this context, teachers should be obliged to develop creativity regularly with a contemporary education approach in preschool education. For this reason, innovative education approaches are considered important starting from preschool period (Oğuzkan, Demiral ve Tür, 2001). In this context, the STEM approach is outstanding. The STEM approach is aimed at removing the content boundaries of the information and addressing the problems in a holistic interdisciplinary perspective and creating alternative solutions to the problems. When the preschool education program implemented in our country in the context of STEM approach is examined, it is seen that the objectives of the MoNE 2013 Pre-School education program are almost the same. As a result of the studies and researches carried out by the Ministry of National Education, it was emphasized that the STEM approach is suitable for preschool education and contributes to the development of the dimension of creativity. Despite the positive results obtained from these studies, it can be said that the studies on the effect of STEM approach on children in preschool education are limited. The aim of this study is to reveal the effect of STEM activities developed on the creativity levels of preschool children.

\section{Method}

In this study, in order to reveal the effects of STEM approach-based activities on the creativity of preschool students, a pre-test-post-test semi-experimental pattern with quantitative research methods was used in the study. The sample group consisted of a total of 60 students and 4 preschool teachers, including the experimental group and the control group studying in the 5-6 age group classes. Torrance Creative Thinking Figural Test A and B Form was used as data collection tool. 


\section{Results}

In STEM activities, students analyze daily life problems, find solutions specific to the problem and form the prototype of the solutions they find with simple materials, creativity and creativity sub-dimensions; Fluency, originality, enrichment, abstraction in the titles, resistance to early closure results significantly increased. It has been determined that there is a decrease between the pre-test creativity total score and sub-evaluation dimensions point averages and post-test creativity total score and the sub-evaluation dimensions score averages in the students who are practicing traditionally.

\section{Discussion and Conclusion}

When the total creativity scores of the experimental group and the control group were examined after the implementation of STEM activities; It is seen that there is a significant difference in favor of the children in the experimental group. It was observed that the students in the experimental group increased significantly compared to the total creativity scores of the children in the control group. Yildirim (2014) examined the effect of creative problem-solving activities in which children produce various solution suggestions on the creativity of preschool children and concluded that there was an increase in the mean score of children in the experimental group, while the creativity total score in the control group decreased slightly. When the fluency scores of the experimental group and the control group were examined before and after the STEM activities; It is seen that the fluency scores of the experimental group increased significantly compared to the fluency scores of the children in the control group. Akdağ and Güneş (2017) stated in their study that after the STEM activities, students' creativity increased, their skills of using time improved and they produced many solutions (fluency) in a short time. When the originality scores of the experimental group and the control group were examined before and after the STEM activities; It is seen that the originality scores of the experimental group increased significantly compared to the originality scores of the children in the control group. Ince, M1s1r, Küpeli ve Firat (2018) concluded that, after the implementation of STEM activities, children in the intervention group produced more original ideas than children in the comparison group. When the enrichment scores of the experimental group and the control group were examined before and after the STEM activities; It is observed that enrichment scores of the experimental group increased significantly compared to the enrichment scores of the children in the control group. Özçelik and Akgündüz (2017) concluded that students can redesign the activities performed with different perspectives in different ways and with different materials. When the abstraction scores of the titles belonging to the experimental group and the control group were examined before and after the STEM activities; It is seen that the abstraction scores of the experimental group titles significantly increased compared to the abstraction scores of the children in the control group. Yildırım (2014) concluded that this situation, which is given by children by identifying them with the situations in problem solving activities, increases the abstraction point averages of the titles. When the early closure resistance scores of the experimental group and the control group were examined before and after the STEM activities; In the experimental group, the early closure resistance scores increased significantly compared to the early closure resistance scores of the children in the control group. 


\section{GİRİŞ}

Bilim ve teknolojinin hızlı bir şekilde ilerlemesi şüphesiz yaşamı kolaylaştırırken sosyal hayatı çok daha karmaşı hale getirmekte, birey açısından akıl yürütmesi ve yaratıcı fikirler üretmesi gereken yeni sorunlar doğurmaktadır. Günümüzde eğitimin işlevlerinden biri öğrencilere yaşam için gerekli olan becerileri kazandırmaktır. Bu becerilerin kazandırılması ancak öğrencilerin var olan yeteneklerini kullanabilmelerini sağlayacak ve bu yeteneklerini geliştirecek şekilde düzenlenen öğrenme ortamlarıyla mümkün olmaktadır. Bu bağlamda temel eğitim, özellikle okulöncesi eğitimi bireyin yaşamında karşı karşıya kaldığı problemlere yaratıcı çözümler veya durumlara yaratıcı fikirler üretmesi açısından oldukça önemlidir (Millî Eğitim Bakanlığı [MEB], 2013).

Yaratıcılık, çocuklarda doğuştan var olan bir özelliktir ve her çocuk yaratıcı olma yeteneğine sahiptir. Yaratıcılık olarak nitelendirdiğimiz yetenek, çocuklarda değişimin, yeniliğin, uyarlayıc1, güdümleyici ögesidir. Aynı zamanda günlük hayatın önümüze çıkardığı sorunları çözümlemek, yorumlamak için kullanılan bir yetenektir. Torrance (1965) yaratıcıllğı, geliştirdiği yaratıcı düşünme testini temel alarak, sorunlara karşı duyarlı olma, çözüm olanakları geliştirme, test etme daha sonra da verileri paylaşma olarak tanımlar. Cropley (2001) yaratıcılığın, farklı bağlantılar kurma ya da alışılmadık çözümler bulmayla ilgili olduğunu ifade eder. Aslan (2001) yaratıcıllğın, kendine özgü bir problem çözme sürecini kapsayan, bireyin zekâ unsurlarını alışılmadık ve üretime dönük kullandığı bilişsel bir yetenek olduğunu belirtir. Tanımlardan yaratıcılık performansının, problemi fark etmeyi, farklı düşünmeyi ve çözüm geliştirmeyi gerektirdiği, özellikle de problemi fark edebilmenin son derece önemli olduğu anlaşılmaktadır (Çakır, Yalçın ve Yalçın, 2019). O halde var olması gereken eğitim ortamı öğrencilerin rahat hissedebilecekleri, bir problem veya sorun olduğunda onu anlayabilecekleri, çözüm yollarını deneyebilecek firsat bulabilecekleri şekilde düzenlendiğinde öğrencilerin potansiyellerini ortaya koymaları çok daha kolaylaşacaktır (Özerbaş, 2011).

Yaratıcı düşünmenin gelişiminin hayatın ilk yıllarında, bireyin erken çocukluk evresinde başladığ1 bilinmektedir (Aslan, Aktan ve Kamaraj, 1997). Okulöncesi dönemde çocuklar oyuncak askerleri için kale, bebekleri için evler veya yataklar, hayvanları için barınaklar veya arabaları için garaj inşa etmekte ve çeşitli araç ve materyalleri kendi amaçları doğrultusunda kullanarak bir şeyler tasarlamaktadır (Roberts, 2003). Bu dönemdeki çocukların tasarım uygulamalarına karşı bu doğal meraklarından dolayı okulda veya okul dışında oynadığı oyunların birçoğunun tasarım aktivitesi özelliği taşıdığ1 görülmektedir. Fortus ve diğerleri (2004) çocukların oyunlarını incelendiği çalışmalarında, öğrencilerin tasarıma dayalı oyunlara ilgilerinin çok fazla olduğunu ve bu oyunların 
STEM yaklaşımının bileşenlerinden biri olan mühendislik alanının birçok özelliğini taşıdığını belirtmektedir. Benzer olarak Atik (2019) yaptığı çalışmasında, tasarıma dayalı aktivitelerin okul öncesi çocukların günlük aktivitelerine oldukça yakın olduğunu belirtmektedir. Wendel (2008) çocukların bu doğal meraklarından dolayı, tasarım ve inşa etmenin, deney ve araştırma yapmaya göre çocukların doğasına daha uygun olduğunu ileri sürmektedir. Ayrıca çocuklar bu dönemde hem kavramsal öğrenme kapasitesine hem de muhakeme ve akıl yürütme için gerekli olan temel süreç becerilerine sahiptir (National Council for Teacher Education [NRC], 2012). Çocuklar tasarlayacakları modeller için gerekli malzemeleri, yapısal (Bu çitin yüksekliği atı içerde tutmak için yeterli midir?), güç (Duvar çatının ağırlığına dayanabilecek mi?) ve denge (Devirmeden kaleyi nasıl ayakta tutabilirim?) gibi fonksiyonları göz önüne alarak seçer ve farklı şekillerde onları birleştirir. Aynı zamanda çocuklar modellerinin ayakta kalması, sallanması veya yıkılmasının malzemelerin özelliklerine, etki eden kuvvete ve modelin şekline bağlı olduğunun da farkındadırlar (Hoisington and Winokur, 2015). Çocuklar bu tür tasarıma dayalı eğitsel oyunlarda yaşadıkları deneyimler ve yaptıkları gözlemler sayesinde bilim ile mühendisliği birleştirir, kendilerinin oluşturdukları bilgiler ve yaptıkları açıklamalar ile etraflarındaki fiziksel dünyayı anlamaya ve açıklamaya çalışır. Yaptıkları bu açıklamalar genellikle bilimsel olarak (uzun bina yapmak için uzun blokları kullanmamız gerekir) doğru olmamasına rağmen merak ve deneyimin sürekliliği sayesinde fen ile mühendisliği birleştirme anlayışını geliştirir (Hoisington and Winokur, 2015). Bu tasarım etkinlikleri çocuklara sadece fen, matematiksel düşünme ve mühendislik (STEM) alanlarında anlamlı tecrübeler sağlamakla kalmamakta, aynı zamanda çocukların motor becerilerini ve yaratıcı becerilerini geliştirmekte ve gerçek bir mühendisliğin iskeletini (temelini) oluşturmaktadır (Zan ve Geiken, 2010; Clements ve Sarama, 2016; Gilliam vd., 2017; Kanter, 2010).

Bu bağlamda okul öncesi eğitimde çocukların yaratıcı düşünme becerilerini geliştirebilmek için probleme yönelik mühendislik tasarım uygulamaları akıllıca bir yol olarak görülebilir. Araştırmacılar mühendislik tasarımına dayalı STEM eğitimindeki çocukların araştırarak, problem çözerek, sorular sorarak öğrenen birer araştırmacı olarak doğduğunu savunur (TUSİAD, 2017; Balat ve Günşen, 2017; Uğraş 2017; Polat ve Bardak, 2019; Çakır, Yalçın ve Yalçın, 2019). Atman ve arkadaşları (2008) herhangi bir mühendislik tasarım sürecinin kullanıldığı bir sınıfta öğrenciler bir sorunun birden fazla yolla temsil edilebileceğini ve sorunun birden fazla yolla çözülebileceğini ve bu yolların test edilerek en etkili çözüm için sürecin bir döngü halinde tekrar edilebileceğini öğrendiklerini belirtmektedir. Ceylan (2014) STEM eğitimine yönelik hazırlanan öğretim tasarımlarının öğrencilerin yaratıcılık alanlarını üst seviyelerde geliştirdiğini ifade etmiştir. Fox and Schirrmacher, (2014) ise eğitimin ve yaşamın temelini oluşturan okul öncesi yıllarında yaratıcılluğın desteklenmesinin büyük önem taşıdığını, Çocuk Eğitimi Uluslararası Derneği’nin vurguladığ1 
toplumda karşılaşılan günlük hayat problemlerini çözebilecek yaratıcı bireylerin yetiştirilmesi hedefinin mühendislik tasarımının yer aldığı öğrenme ortamları sayesinde kazandırabileceğini ifade etmektedir.

STEM eğitimi çerçevesinde mühendislik tasarımı, STEM eğitim yaklaşımı için gerçek yaşam bağlamı sağlayarak anlamlı öğrenmenin gerçekleştirilmesine imkân tanıyan ve fen, matematik eğitimi bağlamında diğer STEM disiplinlerinin entegrasyonunu sağlayan pedagojik bir araçtır (Billiar, Hubelbank, Oliva and Camesano, 2014; Felix, Bandstra and Strosnider, 2010). Billiar ve diğerleri (2014) göre tasarım sürecinin problem-çözme doğasından ve disiplinlerin birbirine bütünleştirme becerisinden dolayı STEM ders etkinlik geliştirmede içerik ve çatı sağlaması bakımından mantıklı bir yol olarak görülmektedir. Bers and ve Postmore (2005) göre ise mühendislik tasarım sürecinin öğretmenlere STEM etkinlikleri geliştirmede bir mekanizma sağlarken aynı zamanda sınıfta mühendislik tasarım öğretiminde onların güven ve beceri kazanmasına yardım eder. Mühendislik tasarım sürecinin yer aldığı STEM etkinliklerinde bireyler bir ürün tasarlamakla birlikte problemi anlayıp çözmeye çalısmakta, birden fazla çözüm önerisi sunmakta, problemi içselleştirdiği için beklenmedik zorluk ve problemler ile başa çıkması konusunda yetkinlik kazandırmakta ve olası çözüm önerilerini sunarken yaratıc1lıklarını kullanmaktadır (Fortus ve diğerleri, 2004; Doppelt, vd., 2008; Mentzer, 2011; Hacioğlu, Yamak ve Kavak, 2016).

Alan yazın incelendiğinde okulöncesinde STEM eğitimi çerçevesinde mühendislik tasarıma dayalı çeşitli proje ve programlar yer almakta ve bu programlarda mühendislik tasarım yöntemleri kullanılarak çeşitli çalışmalar yapılmaktadır. Örnek olarak; Engineering for Kids [EFK] projesi bu projelerden biridir. Çocukları doğuştan mühendis olarak gören bu proje, 4-14 yaş aralı̆̆ındaki çocukların problem çözme yetisine olumlu yönde etki etmeyi ve mühendisliği hem eğlenceli hem yaparak yaşayarak öğretmeyi amaçlamaktadır. (Engineering For Kids [EFK], 2018). Bu projede “Sor, Düs̆̈̈n, Tasarla, Yap, Test Et, Geliştir” basamaklarının yer aldığ1 döngüsel bir MTS modeli kullanılmaktadır. Diğer bir MTS modeli ise okulöncesi öğretmenlerine yönelik geliştirilen Cultivating Young Scientists [CYS] programinda kullanılan ve Engage-Explorer-Reflect [EER] "Girme-Keşfetme-Yansıtma" aşamalarından oluşan MTS modelidir. EER-MTS modeli 3, 4 ve 5 yaş öğrencilerin yer aldığı ana okul sınıflarda uygulamaktadır (Chalufour, Hoisington and Worth, 2004).

Yaygın olarak kullanılan okulöncesi mühendislik tasarım modellerinden biri de Engineering Design Process [EDP] modelidir. Bu model Amerika'da mühendislik eğitimini okul programına dâhil eden 
Massachusetts Eğitim Departmanı (Massachusetts Department of Education-MDOE, 2006) tarafından geliştirilen "Mühendislik Temeldir (Engineering is Elementary- EİE)" proje kapsamındaki 3-5 yaş grubu çocuklar için "Engineering for Wee Kids" ve 5-6 yaş grubu çocuklar için "Engineering for Kindergarden Kids" programlarında kullanılan bir MTS modelidir. Bu programlarda öğrencilerin mühendislik bilgi ve becerilerini geliştirmek için kullanılan EDP-MTS modeli diğer modeller gibi problem ve sorunları ile keşfetme adımıyla başlayıp, uygun kriterleri seç, tasarla ve yarat adımı ile devam edip kriterlere göre test et ve geliştirme adımıyla sona ermektedir (Engineering is Elementary [EIE], 2018).

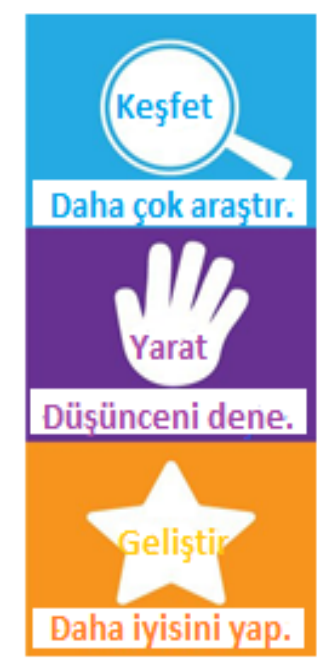

Şekil 2. EDP-MTS Modeli (MDOE, 2006)

Ayrıca EDP-MTS modeli NASA Eğitim merkezi tarafindan EİE programı çerçevesinde okul öncesi eğitim kademelerine yönelik "STEM Lesson From Space" programı altında STEM derslerinde kullanılmaktadır (National Aeronautics and Space Administration [NASA], 2018). Ayrıca bu çalışmada EDP-MTS yöntemi okul öncesi STEM etkinlikleri oluşturmada bir tasarım yöntemi olarak benimsenmiştir.

Görüldüğü gibi STEM bağlamında yaratıcı bir girişim olan mühendislik tasarım süreci okulöncesi eğitimde birçok modelle tanımlanmaktadır. $\mathrm{Bu}$ modellerde problemin tanımlaması, olası çözümlerin ortaya çıkarılması, çözümlerin analiz edilmesi, test edilmesi, değerlendirilmesi ve gerekiyorsa çözümün yenilenmesi, fikirlerin sunumu, iletişim gibi benzer adımlar bulunmaktadır (Brunsell, 2012). 


\section{Problem durumu}

Günümüzde iyice karmaşıklaşan çevredeki çeşitli problem durumlarının çözülebilmesi açısından, bireylerin yaratıcılık becerilerinin çocukluktan başlayarak geliştirilmesi öğrenmenin önemli bir boyutunu oluşturmaktadır (Öncü, 2003; Davaslıgil, 1994). Türkiye İş adamları Derneği [TÜSİAD] (2017) tarafindan yayımlanan "STEM ve Geleceğin Meslekleri" isimli rapora göre toplumun ve endüstrinin her işin üstesinden gelebilen, hayal gücü yüksek, yaratıcı ve geleceğe önemli katkı sağlayacak bireylere bağımlılığın her geçen gün artmaktadır. Diğer taraftan özellikle okul öncesi dönemde çocuklar tasarıma dayalı oyunlara oldukça meraklıdırlar ve yaptıkları tasarımlarla bilim ve mühendisliği birleştirirler. Araştırmalar (Atik, 2019; Yıldırım ve Türk, 2017; Alan, 2020; Fox ve Schirrmacher; 2014, MEB STEM Eğitim Raporu; 2016) eğitimin ve yaşamın temelini oluşturan okul öncesi yıllarında yaratıcılığın desteklenmesinin büyük önem taşıdığını, toplumda karşılaşılan günlük hayat problemlerini çözebilecek yaratıcı bireylerin yetiştirilmesi hedefinin STEM yaklaşımının yer aldığı öğrenme ortamları sayesinde kazandırılabileceğini belirtmektedir. Örnek olarak; Siew, Amir ve Chong (2015) ile Çakır, Yalçın ve Yalçın (2019) STEM yaklaşımının okul öncesi eğitimde yaratıcılı̆̆ın gelişimini olumlu yönde etkilediğini ortaya çıkarmıştır. Bir başka çalışmada ise Eroğlu ve Bektaş (2016) tasarıma dayalı STEM etkinlikleri sayesinde okulöncesi öğrencilerinin STEM mesleklerine ilgilerinin artmasının yanında 21. yüzyıl becerilerinden olan yaratıcılık, üretkenlik ve sorumluluk bilincini geliştirmede etkili olduğunu ortaya çıkarmıştır.

Ülkemizde de özellikle son yıllarda STEM bağlamında okulöncesi eğitim programları incelendiğinde ise 2013 yllından beri okulöncesi eğitim programlarına mühendislik tasarım uygulamalarının doğrudan entegre edilmediği, fakat Milli Eğitim Bakanlı̆̆1 (MEB, 2019) tarafindan yayımlanan tasarıma dayalı STEM etkinliklerinin yer aldığ1 Okulöncesi Etkinlik Havuzu web sitesi ve Kazanım Merkezli STEM Uygulamaları isimli rehber kaynak etkinlikler ile okulöncesi sınıflarda mühendislik tasarım çalışmalarının desteklendiği görülmektedir. Bunlarla birlikte çocuklarda küçük yaşta STEM meslek farkındalığ1 oluşturmak için "Küçük Mühendisler-Evin Küçük Mühendisleri” ve "Bal arıları projesi-kız mühendisler" gibi projeler de MEB desteğiyle yürütülmektedir.

Bu bağlamda ülkemizde yapılan çalışmalar incelendiğinde okul öncesi dönemin önemi, gerekliliği bununla birlikte okul öncesi dönemde STEM yaklaşımının ve STEM etkinliklerinin önemi ve gerekliliği, okul öncesi öğretmenlerinin STEM eğitim uygulamaları hakkındaki düşünceleri, okul öncesi eğitimde STEM ve sanatın STEM disiplinleri ile bütünleştirilmesine dayanan STEM eğitimi uygulamalarının yapıldığı ortaya çıkmaktadır (Alan, 2020; Atik, 2019; Aktürk ve Demircan, 2017; Balat ve Günşen, 2017; Çakır, Yalçın ve Yalçın, 2019; Polat ve Bardak, 2019; Tank ve diğerleri, 
2018; Tippett ve Milford, 2017; Uğraş, 2017). Yapılan çalışmalardan elde edilen olumlu çıktılara rağmen STEM eğitimin okulöncesi eğitime entegre edilerek çocuklar üzerinde etkisini yaratıcı düşünme gibi farklı açılardan inceleyen çalışmalara ihtiyaç olduğu söylenebilir. Özellikle mühendislik tasarım yönteminin okulöncesine entegrasyonuna yönelik gerçekleştirilen çalışmalar, erken yaştaki çocukların mühendislik tasarım sürecini öğrenmesine ve onların yaratıcı düşünme becerilerinin gelişimine yönelik öneriler sunulmasını sağlayabilir. Bu bağlamda çalışmanın amacı geliştirilen mühendislik tasarıma dayalı STEM etkinliklerinin okul öncesi dönem çocuklarının yaratıcı düşünmesine etkisini belirlemektir.

\section{YÖNTEM}

\section{Desen}

Bu çalışmada mühendislik tasarıma dayalı STEM etkinliklerinin okulöncesi öğrencilerinin yaratıcı düşünmesine etkisini belirlemek için nicel araştırma desenlerinden biri olan kontrol gruplu ön testson test yarı deneysel desen kullanılmıştır (Büyüköztürk, 2007). Deneysel desen, değişkenler arasındaki neden-sonuç ilişkilerini ortaya çıkarmak amacıyla kullanılan araştırma desenleri şeklinde tanımlanmaktadır (Büyüköztürk, 2007). Yarı deneysel desenin amacı ile deneysel desenin amacı hemen hemen aynıdır. Aralarındaki farklılık, yarı deneysel desende, kontrol ve deney gruplarının rastgele olmayıp belirli kriterlere göre seçilmesidir (Ekiz, 2003; Karasar, 2006).

Çalışma grubunu 2018-2019 eğitim öğretim yllının güz döneminde Rize İl Milli Eğitim Müdürlüğüne bağlı bir resmi ilkokulun anasınıfinda 5-6 yaş grubu sınıflarında görev yapan 4 okul öncesi öğretmen ve onların öğrencileri $(\mathrm{N}=60)$ oluşturmaktadır. Bu araştırmada, deney ve kontrol grubunun seçiminde rastgele atama yapılmamış, okul öncesi öğretmenlerinin STEM etkinliklerini sinıflarında uygulamaya gönüllü olması, okul idarecilerinin STEM etkinliklerini uygulamaya izin vermesi, öğrencilere Torrance Yaratıcı Düşünce Testi Şekilsel Form A ve Form B testlerinin uygulanmamış olması ve öğrencilerin gelişim özelliklerinin birbirine yakın olması aranan özelliklerdendir. Araştırmada kullanılan desende, deney grupları üzerinde etkisi incelenen bağımsız değişken ise, tasarıma dayalı STEM ders etkinlikleridir. Çalışma grubuna ait özellikler Tablo 1'de ayrıntılı bir biçimde verilmiştir. Aynca okulöncesi okulda araştırma yapmak için Rize Milli Eğitim Müdürlügünden gerekli olan izinler alınmıştır. 
Tablo 1. Çalışma grubuna ait özellikler

\begin{tabular}{|c|c|c|c|c|c|c|}
\hline $\begin{array}{l}\text { Çalışma } \\
\text { Grupları }\end{array}$ & $\begin{array}{l}\text { Öğretmenin } \\
\text { Kodu }\end{array}$ & $\begin{array}{l}\text { Öğretmenin } \\
\text { Mesleki } \\
\text { Tecrübesi }\end{array}$ & $\begin{array}{l}\text { STEM Ĕ̆itim } \\
\text { Deneyimi }\end{array}$ & Okullar & $\begin{array}{l}\text { Yaş } \\
\text { Grubu }\end{array}$ & $\begin{array}{l}\text { Örneklem } \\
\text { Grubu }\end{array}$ \\
\hline \multirow{3}{*}{$\begin{array}{l}\text { Deney } \\
\text { Grubu }\end{array}$} & Aslı & 3 yil & Yok & $\begin{array}{l}\text { X İlköğretim } \\
\text { okulu }\end{array}$ & $5-6$ & $\begin{array}{l}17(8 \mathrm{k} 1 z, 9 \\
\text { erkek) }\end{array}$ \\
\hline & Fatma & 15 y1l & Yok & $\begin{array}{l}\text { X İlköğretim } \\
\text { okulu }\end{array}$ & $5-6$ & $\begin{array}{l}\text { 13(5kız,8 } \\
\text { erkek) }\end{array}$ \\
\hline & Canan & 5 yil & Yok & $\begin{array}{l}\text { X İlköğretim } \\
\text { okulu }\end{array}$ & $5-6$ & $\begin{array}{l}20(9 \mathrm{k} 1 \mathrm{z}, 11 \mathrm{erk} \\
\mathrm{ek})\end{array}$ \\
\hline $\begin{array}{l}\text { Kontrol } \\
\text { Grubu }\end{array}$ & Bahar & 7 y1l & Yok & $\begin{array}{l}\text { X İlköğretim } \\
\text { okulu }\end{array}$ & $5-6$ & $\begin{array}{l}10(7 \mathrm{k} 1 z, 3 \\
\text { erkek })\end{array}$ \\
\hline
\end{tabular}

Tablo 1' de görüldüğü hem deney grubu hem de kontrol grubu kadın öğretmenlerden oluşmakta ve öğretmenler STEM eğitimi almamıştır. Ayrıca okulöncesi sınıf mevcutları az olduğundan deney ve kontrol grupları 2'şer sinıftan oluşmakta ve toplam 60 çocuk ve 4 okul öncesi öğretmen örneklem grubunu oluşturmuştur. Deney ve kontrol grubunun, okul öncesi öğretmenlerinin çocukların bilişsel ve psiko-motor beceriler hakkında verdikleri genel bilgiler doğrultusunda gelişim özellikleri bakımından birbirine denk olduğu söylenebilir. Öğretmenlerin verdikleri bu bilgiyi Tablo 3'deki deney ve kontrol grup öğrencilerin yaratıcıllk ön test değerlerinin birbirine yakın (deney grubunun ön test değeri 43,13 ve kontrol grubunun ön test değeri 42,50) olmas1 da desteklemektedir.

\section{Veri Toplama Araçları ve Analizleri}

Alanda uzman kişilerden alınan bilgilere ve incelenen çalışmalara göre (Atay, 2009; Yıldırım, 2014; Ülger, 2014) erken çocukluk evresinde yaratıcı düşünme imgelemle başlayıp çizimle devam etmektedir. Diğer taraftan okul öncesi dönemde öğrencilerin okuma yazma bilmedikleri için ve öğrencilerin resimleme yoluyla daha kolay ve rahat biçimde yanıt vereceği sonucuna varılarak Çalışmada veri toplamak amacıyla Aslan (2001) tarafinda Türkçeye adapte edilen Torrance Yaratıcı Düşünme Testi [TYDT] Şekilsel A ve B formları kullanılmıştır. Torrance Yaratıcı Düşünme Testi şekilsel A ve B formları 3'er bölümden oluşmaktadır. A formu; resim oluşturma, resim tamamlama ve paralel çizgiler faaliyetlerinden oluşmaktadır. B formu ise; resim oluşturma, resim tamamlama ve doğrular faaliyetlerinden oluşmaktadır. Çalışmada TYDT A formu ön test olarak ve B formu son test olarak uygulanmıştır.

Aslan (2001), TYDT’nin Türkçe versiyonunu oluşturmak için okul öncesinden üniversiteye kadar birçok yaş gruplarından veri toplayarak testin dilsel eşdeğerlik, güvenirlik ve geçerliliğini sağlamaya çalışmıştır. Testin orijinal ve Türkçe çeviri formundan elde edilen puanlar pearson-moment çarpım korelasyon katsayısı formülü ile hesaplanmış ve $\mathrm{p}<.01$ seviyesinde anlamlı bulunmuştur. İç tutarlık 
metodu uygulanarak güvenirlik çalışmaları yapılmış, İç tutarlık katsayısı 0,71 olarak tespit edilmiş ve testin tüm yaş grupları için güvenilir olduğuna karar verilmiştir. Geçerlilik çalışmaları kapsamında ise testin şekilsel yaratıcılık bölümü için madde ayırt ediciliği analizlerinde her yaş gruplarındaki denek sayıları aynı olmak üzere ilişkisiz grup t-testi sonucuna göre $\mathrm{p}>.01$ düzeyinde anlamlı farklılık elde edilmiştir. Bu analiz sonuçlarına göre TYDT Şekilsel A-B Türkçe formu şekilsel yaratıcılık testlerinin beklenen yaratıcı düşünce boyutlarını ölçtüğü kararına varılmıştır.

Bu çalışmada TYDT’nin tüm yaş düzeyinde Aslan (2001) tarafından güvenirlilik ve geçerlilik çalışmaları yapıldığı için araştırmacılar tarafından tekrar bir çalışma yapılmamıştır. Fakat testlerin puanlanması için birinci araştırmac1, Aslan yönetiminde "Torrance yaratıcı düşünme testleri puanlama eğitimi” almıştır. Ayrıca birinci araştırmacı, ilk ölçüme (A formu) ve son ölçüme (B formu) ait testleri 3 hafta sonra tekrar puanlayarak güvenirlik kat sayılarını 0.91 ve 0.89 olarak bulmuştur. Veri toplama aracının bu kadar ayrıntılı biçimde anlatılması makalenin kolay okunabilirliğini ve anlaşılabilirliğini azaltıyor. Bu nedenle özetlenmesi gerektiğini düşünüyorum.

Torrance Yaratıcı Düşünce Şekilsel Testi A ve B formunun analizi için puanlama kılavuzu rehber alınmıştır. Puanlama kılavuzuna göre Torrance Yaratıcı Düşünce Testi A ve B formu; norm dayanıklı ölçüler ve kriter dayanıklı ölçüler (yaratıcı kuvvetler listesi) bakımından analiz edilmiştir. Norm dayanıklı ölçüler; Akıcılık, Orijinallik, Başlıkların Soyutluğu, Zenginleştirme, Erken Kapamaya Direnç olmak üzere 5 alt boyuttan oluşmaktadır. Kriter dayanıklı ölçüler (yaratıcı kuvvetler listesi); Duygusal Dışavurum, Hikâyeyi İfade Edebilme, Hareket veya Faaliyet, Başlıkların İfade Gücü, Tamamlanmamış Şekillerin Sentezi, Çizgi veya Dairelerin Sentezi, Alışılmamış Görselleştirme, İçsel Görselleştirme, Sınırları Uzatma veya Geçme, Espri, Hayal Gücü Zenginliği, Hayal Gücünün Renkliliği, Fantazi olmak üzere 13 alt boyuttan oluşmaktadır (Torrance ve Ball, 1984).

Torrance Yaratıcı Düşünce Testi A ve B formu toplam puanları Statistical Package for Social Sciences (SPSS) 21 programı kullanılarak bağımlı örneklem t-testi ile analiz edilmiştir. Torrance Yaratıcı Düşünce Şekilsel Testi A ve B formu testinden elde edilen ön test - son test toplam puanlarının anlamlılık değerlerinin (sigp) .05 değerinden büyük olması, değerlerin normal dağılıma sahip olduğuna işaret etmiştir. Bu nedenle bu testteki değerlerin parametrik istatistiki testler ile analizine karar verilmiştir (Tablo 2). Bu bağlam da deney grubu ile kontrol grubunda yer alan çocukların ön test ve son test puanları arasında ki bağlantı bağlamlı örneklem t-testi ile test edilmiştir. 
Tablo 2. Deney ve kontrol gruplarının ön test-son test toplam puanlarının kız ve erkeklerin ön test puanlarının normallik analizi

\begin{tabular}{lllll} 
& Grup & \multicolumn{2}{l}{ Kolmogorov-Smirnov $^{\mathrm{a}}$} & \\
\cline { 3 - 5 } Öntest & & Statistic & df & Sig. \\
& Deney &, 085 & 30 &, $200^{*}$ \\
\multirow{2}{*}{ Sontest } & Kontrol &, 118 & 30 &, $200^{*}$ \\
& Deney &, 111 & 30 &, $200^{*}$ \\
& Kontrol &, 139 & 30 &, $147^{*}$ \\
\hline
\end{tabular}

Etkinlik Uygulama Süreci: Bu çalışmada okulöncesi öğrencilerine yönelik geliştirilen STEM etkinlikleri EDP-MTS yöntemi esas alınarak geliştirilmiştir. Çalışmada da fen bilimleri eğitimi bağlamında Uzay Araştırmaları ve Uzayla İlgili Teknoloji, Ulaşım Araçlarının İhtiyaç Durumlarına Göre Yeniden Tasarlanması, Katı Atıkların Geri Dönüşümü, Cisimleri Suda Batıp Batmama Durumuna Göre İnceleme, Canlılarda Oluşumlar ve Dönüşümler ve Hayvan Bakımı ve İhtiyaçlarını Giderme konuların öğretimi için 6 etkinlik geliştirilmiştir. Örnek bir etkinlik Ek-1 'de sunulmuştur. Mühendislik tasarım etkinliklerinin içeriği ve uygulanmasına yönelik detaylar Tablo 3'de sunulmuştur.

Tablo 3. Mühendislik tasarım etkinliklerinin içeriği ve uygulanmasına yönelik detaylar

\begin{tabular}{|c|c|c|c|c|}
\hline Haftalar & Konu & $\begin{array}{l}\text { Etkinlik } \\
\text { Adı }\end{array}$ & Süre & İçerik \\
\hline 07.11.2018 & \multicolumn{3}{|c|}{$\begin{array}{c}\text { Torrance Yaratıcı Düşünme Testi Şekilsel Form A (30 } \\
\text { dakika) }\end{array}$} & Ön Testin uygulanması \\
\hline 13.11.2018 & $\begin{array}{lcr}\text { Hayvan } & \text { Bakımı } & \text { ve } \\
\text { İhtiyaçlarını } & \text { Giderme } & \end{array}$ & $\begin{array}{l}\text { Telaşlı } \\
\text { Hamster }\end{array}$ & 150 Dakika & $\begin{array}{l}\text { Canlıların temel ihtiyaçlarının } \\
\text { önemini fark eder. }\end{array}$ \\
\hline 20.11.2018 & $\begin{array}{lr}\text { Uzay Araştırmaları } & \text { ve } \\
\text { Uzayla İlgili Teknoloji }\end{array}$ & $\begin{array}{l}\text { Sürpriz } \\
\text { Hediye }\end{array}$ & 150 Dakika & $\begin{array}{l}\text { İnsanların duygu ve düşüncelerine } \\
\text { sayg1 duyulması gerektiğini belirtir } \\
\text { ve günlük yaşam teknolojisine } \\
\text { uygun sistem tasarlar. }\end{array}$ \\
\hline 27.11.2018 & $\begin{array}{l}\text { Ulaşım Araçlarının İhtiyaç } \\
\text { Durumlarına Göre Yeniden } \\
\text { Tasarlanması }\end{array}$ & $\begin{array}{l}\text { Minik } \\
\text { Kalplerin } \\
\text { Yardımı }\end{array}$ & 150 Dakika & $\begin{array}{l}\text { Günlük yaşam teknolojisine uygun, } \\
\text { doğal afetlerin zararlarından } \\
\text { korunmak için sistem tasarlar. }\end{array}$ \\
\hline 04.12 .2018 & $\begin{array}{lr}\text { Katı Atıkların } & \text { Geri } \\
\text { Dönüşümüne } & \text { Yönelik } \\
\text { Günlük } & \text { Yaşam } \\
\text { Teknolojisine Uygun Araba } \\
\text { Yapımı }\end{array}$ & $\begin{array}{l}\text { Kirmız1 } \\
\text { Vosvosum }\end{array}$ & 150 Dakika & $\begin{array}{l}\text { Katı atıkların günlük yaşama geri } \\
\text { kazandırılabileceğini fark eder ve } \\
\text { günlük yaşam teknolojisine uygun } \\
\text { araba tasarlar. }\end{array}$ \\
\hline 11.12.2018 & $\begin{array}{lcc}\text { Cisimleri } & \text { Suda } & \text { Batıp } \\
\text { Batmama Durumuna } & \text { Göre } \\
\text { İnceleme } & & \end{array}$ & $\begin{array}{l}\text { İnanılmaz } \\
\text { Kayı̆̆ım }\end{array}$ & 150 Dakika & $\begin{array}{l}\text { Günlük yaşam problemlerine } \\
\text { yönelik çözüm üretir ve çözümünü } \\
\text { tasarlar. }\end{array}$ \\
\hline 18.12.2018 & $\begin{array}{l}\text { Canlılarda Oluşumlar ve } \\
\text { Dönüşümlerde Kurbağa } \\
\text { Gözlemlenmesi }\end{array}$ & $\begin{array}{l}\text { Meraklı } \\
\text { Minikler }\end{array}$ & 150 Dakika & $\begin{array}{l}\text { Canlıların yaşam evrelerine yönelik } \\
\text { gözlem yapar ve gözlemler sonucu } \\
\text { günlük yaşam teknolojisine uygun } \\
\text { tasarım yapar. }\end{array}$ \\
\hline 25.12.2018 & $\begin{array}{r}\text { Torrance Yaratıc1 Düşünme } \\
\text { Saha N }\end{array}$ & $\begin{array}{l}\text { esti Şekilsel } \\
\text { lar1-6 Hafta }\end{array}$ & B -30 Dakika & Son Testlerin Uygulanması \\
\hline
\end{tabular}


Deney grubuna STEM etkinliklerinin uygulanmasından önce araştırmacılar tarafindan öğretmenlere STEM etkinlikleri hakkında ve nasıl uygulanacağı hakkında bilgi verilmiştir. Araştırmacı ilk etkinlikte öğretmenlere uygulama boyutunda yardım ederken geri kalan etkinliklerde herhangi bir müdahalede bulunmamıştır. 2 okulöncesi öğretmeni tarafindan 6 hafta boyunca STEM etkinlikleri uygulanmıştır. Öğretmenler tarafindan tüm etkinlikler hemen hemen aynı hafta içerisinde uygulanmıştır. Yapılan sınıf uygulama sürecinde sınıflarda eşit sayıda kız ve erkek öğrencinin olmaması nedeniyle öğretmenler tarafından kişi sayısı 5-6 olacak şekilde heterojen gruplar oluşturulmuştur. Böylece grup uyumluluğunun tam olarak sağlanabilmesine ve performansın iyi bir şekilde sergilenmesine imkân tanınmıştır. Etkinliklerde kullanılacak basit malzemeler öğretmenler tarafindan temin edilmiş ve her etkinlik için yeni malzemeler temin edilmiştir. Etkinlik sürecinde; öğretmen, ders başlangıcında öğrencilere A3 boyutunda resim kartlarını kullanarak problem durumunu anlatmış ve daha sonra probleme yönelik öğrencilerle beyin firtınası yapmıştır. Öğrencilerin problem durumunu daha iyi anlamaları için A4 boyutunda problem durumunu anlatan resim kartları her bir gruba karışık şekilde verilmiş ve öğrencilerden hikâye kartlarını anlatılan problem olay örgüsüne göre dizmeleri istenmiştir. Bu sırada öğretmen her grubu gezerek grupların hikâye kartlarını doğru bir şekilde dizip dizmediklerini incelemiş ve duruma göre geri bildirim vermiştir. Öğrenciler hikâye kartlarıyla olay örgüsünü doğru bir şekilde oluşturduktan sonra hikâyede var olan problem durumuna çözüm aramışlardır. Çözümler ilk olarak bireysel bir şekilde üretilerek çözümlere yönelik çizimler yapılmıştır. Ardından gruplar içinde üretilen bireysel çözümler arasından bir tane ortak çözüm seçilerek ortak çözüme yönelik ortak bir çizim yapmışlardır. Yapılan ortak çizimden sonra öğrenciler gruplar halinde her türlü malzemenin yer aldığı malzeme masasından malzeme seçimi yapmışlar ve tasarım modellerini oluşturmuşlardır. Öğrencilerin malzeme seçimi sırasında öğrencilere herhangi bir kısıtlama getirilmemiştir. Bütün STEM etkinlikleri uygulandıktan sonra 8.haftada ise son test uygulaması yapılmıştır. Etkinlikler öncesi ve sonrasında ölçme araçları araştırmacılar tarafından uygulanmıştır.

Aynı zamanda Canan ve Bahar öğretmenlerin (kontrol grubu) sınıflarında 1. hafta ve 8. hafta ön test-son test uygulaması yapılmıştır. Geriye kalan 6 hafta içerisinde ise sinıflarında düz anlatım, boyama etkinlikleri, soru-cevap etkinlikleri, resim çizme, şekil tamamlama, yapboz yapma, okul bahçesinde aktiviteler ve gösteri yöntemleri gibi öğretmen merkezli geleneksel yöntemleri kullanmışlardır. Canan ve Bahar öğretmenlerin sınıflarında uyguladıkları örnek bir etkinlik olarak İçeri-Dışarı etkinliği verilebilir. Bu etkinlikte; minderler kullanılarak tüm çocukların sığabilecekleri büyüklükte bir çember oluşturulur. Çemberin içinin ve dışının neresi olduğu sorularak çocukların cevapları alınır, çemberin içi ve dışı çocuklara gösterilir. Çocuklara oyun hakkında kısa bir bilgi verilir. İçeri denildiğinde minderlerin üzerinden atlayarak çemberin içerisine girileceği, dışarı 
denildiğinde ise yine minderlerin üzerinden atlayarak çemberin dışarısına çıkılacağı bilgisi verilir. Yönergeler verilirken başlangıçta ardışık olarak içeri ve dışarı komutlanı kullanılır. Oyun kavrandıktan sonra çocukları şaşırtmaya yönelik komutlar (içeri, içeri, dışarı, dışarı vb.) verilir. Dışarı denildiğinde içeride kalan veya içeri denildiğinde dışarıda kalan çocuklar oyundan çıkar. Oyun çocukların ilgisi doğrultusunda devam ettirilir.

\section{BULGULAR}

Araştırmada deney grubunun ve kontrol grubunun yaratıcılık toplam puanları ve Torrance Yaratıcı Düşünce Şekilsel Testinin alt boyutlarının karşılaştırılması yapılıışıtır. Bu bağlam da deney grubu ile kontrol grubunda yer alan çocukların ön test - son test puanları arasında ki bağlantı bağımlı örneklem t-testi ile test edilmiştir.

Tablo 4. Deney ve kontrol grubunun yaratıcılık toplam puanlarına ilişkin bağımlı örneklem t-testi değerleri

\begin{tabular}{ccccc}
\hline Deney / Kontrol Grubu & $\begin{array}{c}\text { Ön/ Son } \\
\text { Test }\end{array}$ & $\begin{array}{c}\text { Mean } \\
\text { (X) }\end{array}$ & $\begin{array}{c}\text { Standart Deviation } \\
\text { (SS) }\end{array}$ & $\begin{array}{c}\text { Kişi Say1s1 } \\
\text { (N) }\end{array}$ \\
Ön Test & 43,13 & 17,93 & 30 \\
& Son Test & 55,43 & 13,11 & 30 \\
Kontrol Grubu & Ön Test & 42,50 & 18,26 & 30 \\
& Son Test & 33,36 & 14,66 & 30 \\
\hline
\end{tabular}

Tablo 4'de görüldüğgü gibi, deney grubunda ön test 43,13 son test 55,43 değerine ulaşmıştır. Kontrol grubunda ön test 42,50 iken son test 33,36 değerine düşmüştür. STEM etkinlikleri uygulanmas1 sonrasında deney grubu yaratıcllık toplam puan ortalamasında 12,30 değerinde artış gözlenirken, kontrol grubunda ise 9,14 değerinde düşüş görülmektedir. Bu bulgu, STEM etkinliklerinin çocukların yaratıcılıklarında anlamlı derecede artışa neden olduğunu göstermektedir ( $\mathrm{t}=6,304$; $\mathrm{p}<0,05)$.

Tablo 5. Deney ve kontrol grubunun akıcılık puanlarına ilişkin bağımlı örneklem t-testi değerleri

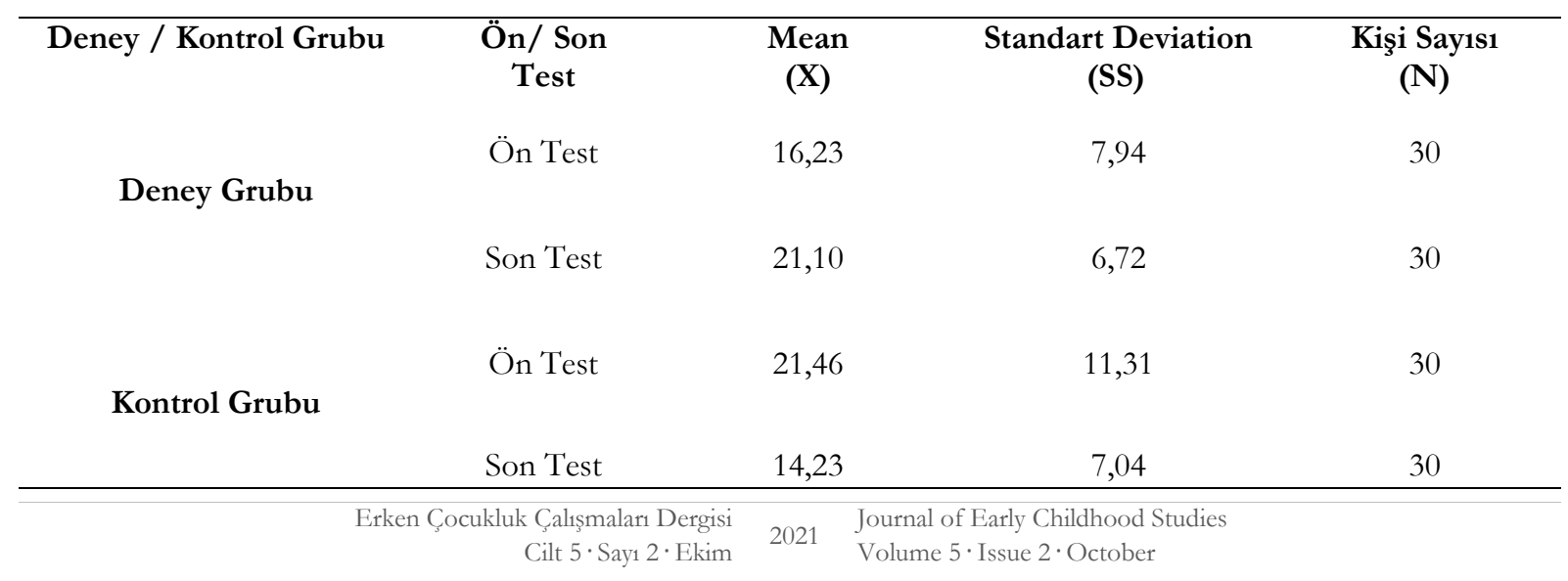


Tablo 5'de görüldüğü gibi, deney grubunda ön test 16,23 son testte 21,10 değerine ulaşmıştır. Kontrol grubunda ön test 21,46 son testte 14,23 değerine düşmüştür. STEM etkinlikleri uygulamas1 sonrasında deney grubunda 4,87 puan değerinde artş yaşanırken, kontrol grubunda 7,23 puan düşüş görülmektedir. Bu bulgu, STEM etkinliklerinin uygulanması sonrasında çocukların aynı sürede ön teste göre son testte daha fazla görsel çizdikleri böylelikle akıcılık puanlarında anlamlı derecede artışa neden olduğunu göstermektedir $(\mathrm{t}=4,27 ; \mathrm{p}<0,05)$.

Tablo 6. Deney ve kontrol grubunun orijinallik puanlarına ilişkin bağımlı örneklem t-testi değerleri

\begin{tabular}{ccccc}
\hline Deney / Kontrol Grubu & $\begin{array}{c}\text { Ön/ Son } \\
\text { Test }\end{array}$ & $\begin{array}{c}\text { Mean } \\
\text { (X) }\end{array}$ & $\begin{array}{c}\text { Standart Deviation } \\
\text { (SS) }\end{array}$ & $\begin{array}{c}\text { Kişi Say1s1 } \\
\text { (N) }\end{array}$ \\
Ön Test & 9,16 & 5,43 & 30 \\
& Son Test & 14,30 & 6,07 & 30 \\
Koney Grubu & Ön Test & 8,80 & 4,65 & 30 \\
& Son Test & 6,43 & 3,31 & 30 \\
\hline
\end{tabular}

Tablo 6'da görüldüğg̈ gibi, deney grubunda ön test 9,16 son testte 14,30 değerine ulaşmıştır. Kontrol grubunda ön test 8,80 iken son testte 6,43 değerine düşmüştür. STEM etkinlikleri uygulaması sonrasında deney grubunda 5,14 puan artış yaşanırken, kontrol grubunda 2,37 puan düşüş görülmektedir. Bu bulgu, STEM etkinliklerinin uygulanması sonrasında çocukların aynı sürede ön teste göre son testte daha sıra dışı orijinal görsel çizdikleri böylelikle orijinallik puanlarında anlamlı derecede artışa neden olduğunu göstermektedir $(t=5,43 ; p<0,05)$.

Tablo 7. Deney ve kontrol grubunun zenginleştirme puanlarına ilişkin bağımlı örneklem t-testi değerleri

\begin{tabular}{ccccc}
\hline $\begin{array}{c}\text { Deney / Kontrol } \\
\text { Grubu }\end{array}$ & $\begin{array}{c}\text { Ön/ Son } \\
\text { Test }\end{array}$ & $\begin{array}{c}\text { Mean } \\
\text { (X) }\end{array}$ & $\begin{array}{c}\text { Standart Deviation } \\
\text { (SS) }\end{array}$ & $\begin{array}{c}\text { Kişi Sayısi } \\
\text { (N) }\end{array}$ \\
Deney Grubu & Ön Test & 6,86 & 1,83 & 30 \\
& Son Test & 9,00 & 2,61 & 30 \\
Kontrol Grubu & Ön Test & 6,83 & 2,03 & 30 \\
& Son Test & 5,16 & 1,66 & 30 \\
\hline
\end{tabular}

Tablo 7'de görüldüğg̈ gibi, deney grubunda ön test 6,86 son testte 9,00 değerine ulaşmıştır. Kontrol grubunda ön testte 6,83 iken bu değer son testte 5,16 değerine düşmüştür. STEM etkinlikleri uygulaması sonrasında deney grubunda 2,15 puan artış yaşanırken, kontrol grubunda 1,67 puan düşüş görülmektedir. Bu bulgu, STEM etkinliklerinin uygulanması sonrasında çocukların aynı 
sürede ön teste göre son testte daha ayrıntılı görsel çizdikleri böylelikle zenginleştirme puanlarında anlamlı derecede artışa neden olduğunu göstermektedir $(t=5,48 ; \mathrm{p}<0,05)$.

Tablo 8. Deney ve kontrol grubunun başlıkların soyutluluğu puanlarına ilişkin bağımlı örneklem t-testi değerleri

\begin{tabular}{ccccc}
\hline Deney / Kontrol Grubu & $\begin{array}{c}\text { Ön/ Son } \\
\text { Test }\end{array}$ & $\begin{array}{c}\text { Mean } \\
(\mathbf{X})\end{array}$ & $\begin{array}{c}\text { Standart Deviation } \\
(\mathbf{S S})\end{array}$ & $\begin{array}{c}\text { Kişi Sayısis } \\
\text { (N) }\end{array}$ \\
Ön Test & 1,43 & 1,35 & 30 \\
& Son Test & 3,13 & 1,87 & 30 \\
Keney Grubu & Ön Test & 1,30 & 0,98 & 30 \\
& Son Test & 0,70 & 0,79 & 30 \\
\hline
\end{tabular}

Tablo 8'de görüldüğg̈ gibi, deney grubunda ön test 1,43 son testte 3,13 değerine ulaşmıştır. Kontrol grubunda ön test 1,30 son testte 0,70 olduğu görülmektedir. STEM etkinlikleri uygulamas1 sonrasında deney grubunda 1,70 puan artış yaşanırken, kontrol grubunda 0,60 puan düşüş görülmektedir. Bu bulgu, STEM etkinliklerinin uygulanması sonrasında çocukların aynı sürede ön teste göre son testte çizdikleri görselleri daha yaratıcı başlıklarla adlandırdığı ve böylelikle başlıkların soyutluluğu puanlarında anlamlı derecede artışa neden olduğunu göstermektedir $(t=5,46 ; p<0,05)$.

Tablo 9. Deney ve kontrol grubunun erken kapamaya direnç puanlarına ilişkin bağımlı örneklem t-testi değerleri

\begin{tabular}{ccccc}
\hline Deney / Kontrol Grubu & $\begin{array}{c}\text { Ön/ Son } \\
\text { Test }\end{array}$ & $\begin{array}{c}\text { Mean } \\
(\mathbf{X})\end{array}$ & $\begin{array}{c}\text { Standart Deviation } \\
(\mathbf{S S})\end{array}$ & $\begin{array}{c}\text { Kişi Sayss } \\
\text { (N) }\end{array}$ \\
Ön Test & 0,00 & 0,00 & 30 \\
Deney Grubu & Son Test & 0,86 & 1,19 & 30 \\
& Ön Test & 0,00 & 0,00 & 30 \\
Kontrol Grubu & Son Test & 0,00 & 0,00 & 30 \\
\hline
\end{tabular}

'Tablo 9' da görüldüğü gibi, deney grubunda ön test 0,00 son testte 0,86 değerine ulaşmıştır. Kontrol grubunda ön testte 0,00 iken bu değer son testte 0,00 olduğu görülmektedir. STEM etkinlikleri uygulaması sonrasında deney grubunda yer alan çocukların erken kapamaya direnç puan ortalamalarında 0,86 puan artışı görülürken, kontrol grubunda yer alan çocukların puan ortalamalarında herhangi bir puan değişimi görülmemektedir. Bu bulgu, STEM etkinliklerinin uygulanması sonrasında çocukların aynı sürede ön teste göre son testte çizdikleri görsellerin belli 
bir çerçeve içerisinde olmadığı ve böylelikle erken kapamaya direnç puanlarında anlamlı derecede artışa neden olduğunu göstermektedir $(t=3,97 ; \mathrm{p}<0,05)$.

Araştırmanın alt problemine ait bulgulara bakıldığında, 5-6 yaş grubu çocuklarına uygulanan STEM etkinlikleri sonunda, çocukların toplam yaratıcılık puanlarında anlamlı bir artış yaşanmıştır. Bununla birlikte akıc1lı, orijinallik, zenginleştirme, başlıkların soyutluluğu ve erken kapamaya direnç alt testlerinde deney grubunda anlamlı bir artış görülmüştür.

\section{TARTIŞMA VE SONUÇ}

STEM etkinliklerinin uygulanması sonrasında deney grubu ve kontrol grubuna ait toplam yaratıc1lk puanları incelendiğinde; deney grubundaki çocukların lehine anlamlı bir farklılı̆̆ın olduğu görülmektedir. Deney grubundaki çocukların; tasarıma dayalı STEM etkinliklerinde günlük yaşam problemlerini analiz etmeleri, probleme özgün birden fazla çözümler bulmaları, buldukları çözümleri istedikleri şekilde çizmeleri, çözümlerin basit malzemelerle prototipini oluşturmaları, prototipleri deneyerek tekrar geliştirmeleri, oluşturdukları prototipleri sunmaları kontrol grubunun ise geleneksel yöntemler içeren etkinlikleri uygulamaları yaratıcılık toplam puanlarının anlamlı derecede artmasında önemli bir faktör olabilir. Alan yazında yer alan çalışmalar incelendiğinde yapılan bu çalışmayla benzer sonuçların olduğu görülmektedir (Ceran, 2010; Dursun ve Ünüvar, 2011; Çetingöz, 2012; Yıldırım, 2014; Soylu, 2016; Aktürk ve Demircan, 2017; Balat ve Günşen, 2017; Uğraş, 2017). Yıldırım (2014), çalışmasında günlük hayat problemlerinin yer aldığı, çocukların çeşitli çözüm önerileri ürettiği yaratıcı problem çözme etkinliklerinin okul öncesi çocukların yaratıc1lı̆ına etkisini incelemiş ve deney grubunun değerlerinde artış görülmüşken, kontrol grubunun değerlerinde düşüş yaşandığ1 sonucuna varmıştır.

Yaratıcı düşünmenin değerlendirme boyutu olan akıcılık, bir problem karşısında yorumlanabilen ve üretilebilen cevap sayısıdır. STEM etkinliklerinin öncesi ve sonrasında deney grubu ve kontrol grubuna ait akıcılık puanları incelendiğinde; deney grubundaki çocukların akıcılık puanlarının ön teste göre son testte arttı̆̆ görülmüştür. Kontrol grubunda ise akıcılık puanlarının ön teste göre son testte azaldığı görülmektedir. Bununla birlikte deney grubu akıcılık puanlarının kontrol grubundaki çocukların akıcılık puanlarıyla karşılaştırıldığında anlamlı derecede artmış olduğu görülmektedir. Uygulanan etkinliklerin çocukların ilgi alanlarına yönelik olması, her bir etkinlikte farklı kazanımların olması, problemler için gruptaki her öğrencinin birden fazla çözüm üretmesi ve taslak çizmesi ve tartışarak bir tasarıma karar verip yapmaları, çözüm üreten çocukların pekiştireçlerle ödüllendirilmesi bu duruma dayanak oluşturmuştur. Kontrol grubundaki geleneksel uygulamalar, çocukların birden fazla fikir üretmesinden ziyade kalıplaşmış bir düşünceyi olduğu gibi 
kabul edip etkinliğin uygulanmasına yöneliktir. Kontrol grubu sınıfındaki öğretmenlerin resim çizme etkinliğinde bir konuya yönelik resim yaptırması ve çocukların çizdikleri resimleri geliştirme sürecinde onların düşüncelerine rehberlik etmek yerine resimlere bir takım eklemeler yapması bu durumun ortaya çıkmasında önemli bir neden olabilir.

Bu doğrultuda deney grubundaki akıcılık puanındaki bu gelişme çocukların STEM etkinliklerinde birden fazla çözüm önerisi bulmaları ayrıca buldukları çözüm önerilerini tasarlayıp çizim yapmaları aynı sürede zamanla daha fazla fikir üretmelerine katkı sağlamış olduğu düşünülebilir. Alan yazında yer alan çalışmalar incelendiğinde yapılan bu çalışmayla benzer sonuçların olduğu görülmektedir (Ceran, 2010; Dursun ve Ünüvar, 2011; Çetingöz, 2012; Yıldırım, 2014; Soylu, 2016; Aktürk ve Demircan, 2017; Akdağ ve Güneş, 2017; Balat ve Günşen, 2017; Uğraş, 2017). Akdağ ve Güneş (2017), yaptıkları çalışmada öğrencilere birden fazla STEM etkinlikleri uygulamış ve STEM etkinlikleri sonrasında öğrencilerin yaratıcılıklarının arttı̆ııı, zamanı kullanma becerilerinin geliştiğini ve kısa zamanda birçok çözüm ürettiklerini (akıcılık) belirtmiştir.

Yaratıcı düşünmenin bir değerlendirme boyutu olan orijinallik ise, var olan çözüm önerilerinin dışında daha özgün çözüm üretebilmektir. STEM etkinliklerinin öncesi ve sonrasında deney grubu ve kontrol grubuna ait orijinallik puanları incelendiğinde; deney grubundaki çocukların orijinallik puanlarının ön teste göre son testte arttı̆̆1 görülmüştür. Kontrol grubunda ise orijinallik puanlarının ön teste göre son testte azaldığı görülmektedir. Bununla birlikte deney grubu orijinallik puanlarının kontrol grubundaki çocukların orijinallik puanlarına göre anlamlı derecede artmış olduğu görülmektedir. Bu doğrultuda çocukların ürettiği çözüm önerilerinin daha özel daha özgün özellikler taşıdığı, daha çok yaratıcı daha orijinal ve daha işlevsel fikirler ortaya koymaları bu durumu desteklemiştir. Kontrol grubu sınıfında ise uygulanan etkinliklerin çocukların orijinal fikirler oluşturmalarına yönelik olmadığı daha çok belirli fikri gerçekleştirmeye yönelik olduğu söylenebilir. Kontrol grubu sınıfinda belirli gün ve haftalara yönelik hazırlanan etkinliklerde çocukların düşüncelerini alıp ürettikleri orijinal fikirleri uygulamak yerine, öğretmenlerin kendi seçtikleri etkinlikleri uygulamayı tercih etmeleri örnek gösterilebilir.

Bu bağlamda deney grubundaki orijinallik puanındaki bu gelişme, her STEM etkinliğinde farklı bir problem durumu ile karşılaşmaları, problemlere yönelik grup içerisinde fikirlerin tartış1ması ve kabul görmesi, sınıf önünde sunulması ve öğretmen tarafından takdir edilmesi, öğrencilerin zamanla daha çok sıra dişı fikirlerini ifade etmesini geliştirdiği söylenebilir. Alan yazında yer alan çalışmalar incelendiğinde yapılan bu çalışmayla benzer sonuçların olduğu öne çıkmaktadır (Ceran, 2010; Dursun ve Ünüvar, 2011; Çetingöz, 2012; Yıldırım, 2014; Soylu, 2016; Aktürk ve Demircan, 2017; 
Balat ve Günşen, 2017; Uğraş, 2017, İnce, Mısır, Küpeli ve Firat., 2018). İnce, Misır, Küpeli ve Firat (2018), çalışmasında 5.sınıf çocuklarına STEM etkinliklerinin uygulanması sonrasında çocukların gelişim alanlarına etkisi incelendiğinde yaratıcllğga olumlu yönde etki ettiği ve deney grubundaki çocukların kontrol grubundaki çocuklara göre daha özgün fikirler ürettikleri sonucuna varmıştır.

Yaratıcı düşünmenin diğer bir değerlendirme boyutu olan zenginleştirme, problem durumuna yönelik çizimlerin daha detaylı ve ayrıntılı olmasıdır. STEM etkinliklerinin öncesi ve sonrasında deney grubu ve kontrol grubuna ait zenginleştirme puanları incelendiğinde; deney grubundaki çocukların zenginleştirme puanlarının ön teste göre son testte arttı̆̆1 görülmüştür. Kontrol grubundaki çocukların zenginleştirme puanlarının ön teste göre son testte azaldığı görülmüştür. Bununla birlikte deney grubu zenginleştirme puanlarının kontrol grubundaki çocukların zenginleştirme puanlarına göre anlamlı derecede artmış olduğu görülmektedir. Kontrol grubundaki uygulamalar, çocukların daha ayrıntılı görseller oluşturmalarından ziyade kalıplaşmış şekiller üzerinden etkinliğin uygulanmasını içermektedir. Kontrol grubu sınıfinda uygulanan şekil tamamlama etkinliğinde çocuklara hazır bir şekil verilip belli bir bölgesinin tamamlanmamış olması ve şeklin nasıl tamamlanması gerektiğinin hafif ince bir çizgiyle belirtilmiş olması aynı zamanda şeklin ne olduğunun önceden çocuklara söyleniyor olması, çocukların ayrıntılandırma içermeyen kalıplaşmış görsellerle etkinlikler gerçekleştirildiğinin bir göstergesidir.

Bu bağlamda deney grubundaki zenginleştirme puanındaki bu gelişmenin ortaya çıkmasının nedeni, öğrencilerin etkinliklerde tasarım çizimlerini nasıl yapacaklarını grup içerisinde tartışmaları ve bu tartışmalar sonucunda çizimlerine son halini vermelerinden kaynaklandı̆̆1 söylenebilir. Diğer taraftan etkinlik sonunda öğrencilerin çizimlerini grupça tahtada ürettikleri model eşliğinde sunacak olmaları onların daha detaylı ve ayrıntılı çizim yapmalarını sağladığı düşünülmektedir. Alan yazında yer alan çalışmalar incelendiğinde yapılan bu çalışmayla benzer sonuçların olduğu görülmektedir (Ceran, 2010; Dursun ve Ünüvar, 2011; Çetingöz, 2012; Yıldırım, 2014; Soylu, 2016; Aktürk ve Demircan, 2017; Balat ve Günşen, 2017; Özçelik ve Akgündüz, 2018; Uğraş, 2017). Özçelik ve Akgündüz (2017), üstün/özel yetenekli öğrencilerle yürüttüğü çalışmasında, mühendisliğin temel ilkelerini ve problem çözme basamaklarını içeren STEM etkinliklerinin çocuklara yaratıcılık, iş birliği, eleştirel düşünme ve iletişim kurma gibi 21. yy. becerileri kazandırdığını tespit etmiştir. Ayrıca Özçelik ve Akgündüz, öğrencilerin STEM etkinliklerden elde ettikleri kazanımları ürün oluşturmada kullanabildiklerini ve öğrencilerin farklı bakış açılarıyla yapılan aktiviteleri farklı şekillerde ve farklı malzemelerle ayrıntılı bir şekilde yeniden tasarlayabildiklerini de ortaya çıkarmıştır. 
Yaratıcı düşünmenin bir değerlendirme boyutu olan başlıkların soyutluluğu, problem durumlarına yönelik üretilen prototiplere var olan isimler dışında daha sıra dişı isimler verebilmektir. STEM etkinliklerinin öncesi ve sonrasında deney grubu ve kontrol grubuna ait başlıkların soyutluluğu puanları incelendiğinde; deney grubundaki çocukların başlıkların soyutluluğu puanlarının ön teste göre son testte arttığı görülmüştür. Kontrol grubunda ise çocukların başlıkların soyutluluğu puanlarının ön teste göre son testte azaldığı görülmüştür. Bununla birlikte deney grubu başlıkların soyutluluğu puanlarının kontrol grubundaki çocukların başlıkların soyutluluğu puanlarına göre anlamlı derecede artmış olduğu görülmektedir. Kontrol grubunda çocukların bir objeye isim verirken sıra dış1 isimler yerine daha çok çizgi film karakterlerinden veya yakın çevresindeki kişilerin isimlerini verdikleri göze çarpmaktadır. Kontrol grubu sınıfındaki uygulamalarda bir eşyanın ismi niteliklerini kapsayacak (renk, şekil, doku) şekilde söylenilmemesi ve daha farklı nasıl bir isim olabilir şeklinde düşünce paylaşımına gidilmemesi örnek gösterilebilir.

Deney grubundaki başlıkların soyutluluğu puanında ki bu gelişme, deney grubundaki çocukların, STEM etkinliklerinde prototiplerine verdikleri isimleri problem hikayelerindeki karakter ve olaylardan esinlenerek üretme çaba içerisinde olmalarından kaynaklanabilir. Ayrıca üretilen bu isimlerin öğrenci sunumları sırasında öğretmen ve diğer öğrencilerden gelen eleştireler doğrultusunda zamanla daha kurgusal boyuta doğru yönelmesi bu durumun ortaya çıkmasında diğer nedeni olabilir. Alan yazında yer alan çalışmalar incelendiğinde yapılan bu çalışmayla benzer sonuçların olduğu öne çıkmaktadır (Ceran, 2010; Dursun ve Ünüvar, 2011; Çetingöz, 2012; Yıldırım, 2014; Soylu, 2016; Aktürk ve Demircan, 2017; Balat ve Günşen, 2017; Uğraş, 2017). Yıldırım (2014), günlük hayat problemlerinin yer aldığı, çocukların çeşitli çözüm önerileri ürettiği yaratıcı problem çözme etkinliklerinin okul öncesi çocukların yaratıcılığına etkisini incelemiş ve deney grubunda yer alan çocukların problem çözme etkinliklerinde yer alan durumlarla özdeşleştirerek başlık verdiği bu durumun başlıkların soyutluluğu puan ortalamalarında artışa sebep olduğu sonucuna varmıştır.

Yaratıcı düşünmenin bir değerlendirme boyutu olan erken kapamaya direnç, problem durumuna yönelik çizimlerde görsellerin tamamlanmadan çizilmesidir. STEM etkinliklerinin öncesi ve sonrasında deney grubu ve kontrol grubuna ait erken kapamaya direnç puanları incelendiğinde; deney grubundaki çocukların erken kapamaya direnç puanlarının ön teste göre son testte artmış olduğu görülmektedir. Kontrol grubundaki çocukların erken kapamaya direnç puanlarının ön teste göre son testte değişimin olmadığı görülmektedir. Bununla birlikte deney grubu erken kapamaya direnç puanlarının kontrol grubundaki çocukların erken kapamaya direnç puanlarına göre anlamlı derecede az miktarda artmış olduğu görülmektedir. Kontrol grubunda uygulanan etkinliklerde 
genellikle görsellerin tamamlanması gerektiği yarım kalan bir görselin başarısız bir çizim olduğu belirtilmektedir. Kontrol grubu sınıfında uygulanan şekil tamamlama veya bir konu hakkında çizilen resmin içerisindeki ögelerin yarım kalmaması sıklıkla öğretmenler tarafından vurgulanıyor olması bu duruma örnek gösterilebilir.

$\mathrm{Bu}$ doğrultuda deney grubundaki erken kapamaya direnç puanında ki bu gelişme, STEM etkinliklerinde dağıtılan karışık hikâye kartlarının belli bir olay örgüsüne göre sıralanması, görsellerin birbirini tamamlayarak devam etmesi ve hikâye kartlarındaki görsellerin keskin hatlarla bitmesi zamanla çizimlerin tamamlanması gerektiğini aşılamış olabilir. Bu bağlamda deney grubundaki çocuklarda erken kapamaya direnç boyutunda az miktarda artış göstermiş olabilir. Alan yazında yer alan çalışmalar incelendiğinde yapılan bu çalışmayla benzer sonuçların olduğu öne çıkmaktadır (Ceran, 2010; Dursun ve Ünüvar, 2011; Çetingöz, 2012; Yıldırım, 2014; Soylu, 2016; Aktürk ve Demircan, 2017; Balat ve Günşen, 2017; Uğraş, 2017). Yıldırım (2014), günlük hayat problemlerinin yer aldığı, çocukların çeşitli çözüm önerileri ürettiği yaratıcı problem çözme etkinliklerinin okul öncesi çocukların yaratıcıllğına etkisini incelemiş ve deney grubunun değerlerinde artış, kontrol grubunun değerlerinde düşüş olduğu sonucuna varmıştır.

Sonuç olarak, 5-6 yaş çocuklarına uygulanan STEM etkinlikleri sonrasında, çocukların yaratıcılık toplam puanlarında anlamlı bir artış görülmüştür. Bununla birlikte akıcılık, orijinallik, zenginleştirme, başlıkların soyutluluğu ve erken kapamaya direnç alt boyutlanında deney grubu lehine anlamlı bir artış olduğu saptanmıştır.

\section{ÖNERİLER}

Araştırmalar öğrencilerin mühendislik tasarım süreci entegre edilmiş STEM etkinliklerine daha uzun süre maruz kalmalarının bu değişimi çok daha pozitif kılacağını savunmaktadır (Balat ve Günşen, 2017; Tank ve diğerleri, 2018; Polat ve Bardak, 2019; Atik, 2019; Alan, 2020). Bu bağlamda geliştirilen etkinliklerin iki aylık uygulama dönemi yerine tüm okul öncesi eğitimi döneminde uygulanması bu durumu değiştirebilir. Bu çalışmada çocukların kısa vadede yaratıcılıklarının gelişmesi bile STEM eğitimi açısından önemli bir kazanım olarak değerlendirilebilir. Diğer taraftan bu çalışmada STEM etkinliklerinde yer alan problem durumları görselleştirilmiş hikâye kartları ile çocuklara anlatılmıştır. Problem durumları kukla ve animasyon gibi farklı araç gereçler kullanılarak anlatılabilir. Örnek olarak Massachusetts Eğitim Departmanı (MDOE, 2006) tarafından geliştirilen Wee Engineer programında yer alan etkinliklerde öğrencilere problem durumlarını aktarmak için eğitimciler tarafindan kukla kullanılmaktadır. Ayrıca çalışmada STEM etkinliklerinde yer alan hikâye senaryoları tamamlanmış bir şekilde çocuklara aktarılmıştır. Hikâye senaryoları yarım bırakılarak 
çocukların hayal güçlerine yönelik tamamlamaları ve kendi problem durumlarını kendileri oluşturmaları istenebilir. Cropley'e (2001) göre problem çözüm sürecinde çocukların problem durumlarının kendilerinin oluşturması problemi daha çok benimsemesine ve çözüme yönelik daha özgün (orjinallik) ve daha çok öneriler (akıcılık) üretmesine sağlar.

Çalışmada STEM etkinliklerinin çocukların yaratıcılık düzeyine etkisi bir bütün olarak değerlendirilmiştir. Fakat geliştirilen STEM etkinliklerinin çocukların yaratıcılık düzeyine etkisi cinsiyete, farklı yaş gruplarına göre incelenebilir. Ayrıca etkinliklerde çocuklar bir mühendis gibi mühendislik tasarım süreci içerisine girmişlerdir, etkinliklerin çocukların STEM meslek farkındalıklarına etkisi araştırılabilir. Diğer taraftan çocukların okul öncesi eğitimine aileleri ile evde yaptıkları etkinliklerinin de etkili olduğu belirtilmektedir (Uğraş, 2017; Aktürk ve Demircan, 2017; Tippett ve Milford, 2017; Çakır ve diğerleri, 2019). Bu bağlamda ailelerin de STEM etkinliklerine katılmaları çocukların yaratıcılıklarının gelişimi açısından oldukça faydalı olacağı düşünülmektedir. $\mathrm{Bu}$ yüzden gelecekteki araştırmalarda ailelerin de yer aldı̆̆ı bir araştırmanın yapılması tavsiye edilmektedir.

\section{KAYNAKÇA}

Alan, Ü. (2020). Okul öncesi dönem çocuklarna yönelik geliştirilen STEM eğitimi programmmn etkililiğinin incelenmesi. Doktora Tezi. Hacettepe Üniversitesi Eğitim Bilimleri Enstitüsü, Ankara, Türkiye, $280 \mathrm{~s}$.

Akdağ, F., Güneş, T. (2017). Enerji konusunda yapılan STEM uygulamaları ile ilgili fen lisesi öğrenci ve öğretmen görüssleri. International Journal of Social Sciences and Education Research. 3(5), 1643-1656.

Aktürk, A., ve Demircan, H. (2017). Okul öncesi dönemde STEM ve STEAM eğitimine yönelik çalışmaların incelenmesi. Ahi Evran Üniversitesi Kırşehir Eüitim Fakültesi Dergisi, 18(2), 757 776.

Aslan, E. (2001). Torrance yaratıcı düşünce testinin Türkçe versiyonu. Marmara Üniversitesi Atatürk Ë̈itim Fakültesi Ë̆itim Bilimleri Dergisi, 14, 19-40.

Aslan, A.E., Aktan, E., ve Kamaraj, I. (1997). “Anaokulu Eğitiminin Yaratıcı Düşünce Üzerindeki Etkisine Yönelik Bir Uygulama.” IV. Ulusal Psikolojik Danısma ve Rebberlik Kongresinde bildiri. Ankara Üniversitesi, Ankara

Atay, Z. (2009). Okul öncesi eğitim kurumlarna devam eden 5-6 ögrencilerinin yas, cinsiyet ve ebeveyn eğitim durumlarna göre incelenmesi: Ereğli örneğgi. Yüksek Lisans Tezi. Selçuk Üniversitesi Sosyal Bilimler Enstitüsü, Konya, Türkiye, 78 s.

Atik, A. (2019). STEM etkinliklerinin bilimsel süreç becerileri üzerine etkisi: 5 yaş örneğ̈i. Yüksek Lisans Tezi. Trabzon Üniversitesi Lisansüstü Eğitim Enstitüsü, Trabzon, Türkiye, 237 s.

Atman, C.J., Yasuhara, K., Adams, R.S., Barker, T.J., Turns, J., Rhone, E., 2008. Breadth in problem scoping: a comparison of freshman and senior engineering students. International Journal of Engineering Education, 42, 234-245. 
Balat, G., ve Günşen, G. (2017). Okul öncesi dönemde STEM yaklaşımı. Akademik Sosyal Arastirmalar Dergisi, 5(42), 337-348.

Billiar, K., Hubelbank, J., Oliva, T., Camesano, T., 2014. Teaching STEM by design. Advances In Engineering Education, 4(5), 1-21.

Brunsell, E. (2012). Integrating engineering and science in your classroom. Arlington, VA: NSTA Press.

Büyüköztürk, S.. (2007). Sosyal bilimler için veri analiẓ el kitabı. Ankara: Pegem A Yayıncılık

Ceran, S. (2010). Yaratıc düs̈̈̈nme teknikleri ile gelistirilen fen etkinliklerinin ögrenci başarıs ve tutumuna etkisi. Yüksek Lisans Tezi. Selçuk Üniversitesi Eğitim Bilimleri Enstitüsü, Konya, Türkiye, $130 \mathrm{~s}$.

Ceylan, S. (2014). Ortaokul Fen Bilimleri Dersindeki Asitler ve Bazlar Konusunda Fen, Teknoloji, Mühendislik ve Matematik Yaklasımı ile Öğretim Tasarmı Hazırlanmasma Yönelik Bir Calısma. Yüksek Lisans Tezi. Uludağ Üniversitesi, Eğitim Bilimleri Enstitüsü, Bursa, Türkiye, 260 s.

Chalufour, I., Hoisington, C., Moriarty, R., Winkour, J. and Worth, K.(2004). The science and mathematics of building structures. Science and Children, 41(4), 30-34.

Clements D. H., and Sarama J. (2016). The Future of ChildrenStarting Early: Education from Pre Kindergarten to Third Grade, 26(2), 75-94

Çalışandemir, F., ve Bayhan P. (2011). Anasınıfı çocuklarının çoklu zeka alanlarının gelişimine deney yöntemiyle verilen eğitimin etkisinin incelenmesi. Mehmet Akif Ersoy Üniversitesi Eğitim Fakültesi Dergisi, 11(9), 180 -207.

Çakır, Z., Yalçın, S., ve Yalçın, P. (2019). Montessori yaklaşımı temelli STEM etkinliklerinin okul öncesi öğretmen adaylarının yaratıcılık becerilerine etkisi. Uluslararası Bilimsel Arasstırmalar Dergisi, 4(2), 392-409.

Çeliköz, N. (2017). Okul öncesi dönem 5-6 yaş çocuklarının yaratıcılık düzeylerinin incelenmesi. Yuldı ₹ournal of Educational Research, 2(1), 1-125.

Çetingöz, D. (2012). Ana sınıfı öğretmenlerinin yaratıcı etkinlikler planlamaya ilişkin görüşlerinin incelenmesi. Mersin University Journal of the Faculty of Education, 8(2), 1-10.

Cropley, A, J. (2001). Creativity in Education and Learning. London: Kogan Page

Davasligil, Ü. (1994). Yüksek Gizilgüce Sahip Lise Öğrencilerinin Yaratıcılıkları Üzerine Deneysel Bir Araştırma. Marmara Üniversitesi Atatürk Eğitim Fakültesi Eğitim Bilimleri Dergisi, 6, 53-68.

Doppelt, Y., Mehalik, M. M., Schunn, C. D., Silk, E., and Krysinski, D. (2008). Engagement and achievements: a case study of design-based learning in a science context. Journal of Technology Education, 19(2), 22-39.

Dursun, M., ve Ünüvar, P. (2011). Okul öncesi eğitim döneminde yaratıcllı̆̆ engelleyen durumlara ilişkin ebeveyn ve öğretmen görüşlerinin incelenmesi. Mehmet Akif Ersoy Üniversitesi Eğgitim Fakültesi Dergisi, 11(21), 110 -133.

Ekiz, D. (2003). Eğitimde araștrma yöntem ve metodlarna giriș: nitel, nicel ve eleștirel kuram metodojileri. Ankara: Anı Yayıncilik.

Engineering is Elementary [EIE] (2018). The Engineering Design Process. 2 Kasim 2017 tarihinde https://eie.org/ adresinden erişildi.

Engineering For Kids of Malaysia(2018). How our bands-on teaching structure can benefit your kids. 29 Kasım 2017 tarihinde https://www.efk.com.my/ adresinden erişildi.

Eroglu, S., ve Bektas, O. (2016). Ideas of science teachers took stem education about STEM based activities. Journal of Qualitative Research in Education, 4(3), 43-67. 
Felix, A.L., Bandstra, J.Z., and Strosnider, W.H.J. (2010, January, 16-19). Design-Based Science for STEM student recruitment and teacher professional development. Midatlantic American Society for Engineering Education Conference, Philadelphia.

Fortus, D., Dershimer, C., Krajcik, J., Marx, W., ve Naaman, R. (2004). Design-Based science and student learning, Journal of Research in Science Teaching, 4(1), 108-110.

Fox, J.E., and Schirrmacher, R. (2014). Çocuklarda sanat ve yaratıctlğgn gelişimi. (A.Aral çev.) Ankara: Nobel Yayıncilik

Gilliam, M., Jagoda, P., Fabiyi, C., Lyman, P., Hill, B., Bouris, A., 2017. Alternate reality games as an informal learning tool for generating STEM engagement among underrepresented youth. Qualitative Evaluation of the Source, Journal of Science Education and Technology, 3, 295-308.

Hacıoğlu, Y., Yamak, H., ve Kavak, N. (2016). Mühendislik tasarım temelli fen eğitiminin fen bilgisi ögretmen adaylarının bilimsel yaratıcılıklarına etkisi. Educational Researches and Publications Association (ERPA) International Congress on Education 2016, 132-132.

Hoisington, C., and Winokur, J. (2015). Reprinted with permission from Science and Children. National Science Teachers Association, 53(1), 44-51

İnce, K., Misır, M., Küpeli, M., ve Firat., A. (2018). 5. Sınıf Fen Bilimleri dersi Yer Kabuğunun Gizemi ünitesinin öğretiminde STEM temelli yaklaşımın öğrencilerin problem çözme becerisi ve akademik başarısına etkisinin incelenmesi. Journal of STEAM Education Bilim, Teknoloji, Mühendislik, Matematik. ve Sanat Eğitimi Dergisi, 1(1), 64-78.

Kanter, D., 2010. Doing the project and learning the content: designing project-based science curricula for meaningful understanding. Science Education, 94, 525-551.

Karasar, N. (2012). Bilimsel araştırma yöntemi. Ankara: Nobel Yayıncilık.

Massachusetts Department of Education(2006). Massachusetts science and technology engineering curriculum framework. 25 Kasim 2017 tarihinde http://www.doe.mass.edu/frameworks/scitech adresinden erişildi.

Mentzer, N. (2011). High school engineering and technology education integration through design challenges. Journal of STEM Teacher Education, 48(2), 103-136.

MEB, (2013). Okul öncesi eğitim programı. Ankara, Türkiye, 114 s.

MEB, (2016). STEM Ë̆itim Raporu. İstanbul, Türkiye, $28 \mathrm{s.}$

MEB, (2019). Ką̧anm Merkęli STEM Uygulamalar. Ankara, Türkiye, 43 s.

Moomaw, S. (2013) Teaching STEM in Preschool and Kindergarten: Activities for intergrading Science, Technology, Engineering, and Mathematics. St Paul, MN: Redleaf Press.

National Council for Teacher Education, 2012. A framework for K-12 science education: Practices, crosscutting concepts, and core ideas. Washington National Academies Press. 14, 43-64.

National Aeronautics and Space Administration, (2018). STEM Lessons From Space: Engineering.24 Kasım 2017 tarihinde https://www.nasa.gov/audience/foreducators/stem-onstation/engineering adresinden erişildi.

Oğuzkan, Ş., Demiral, Ö., ve Tür, G. (2001). Okul öncesinde yaratıcı çocuk etkinlikleri. İstanbul: Y Ya$\mathrm{Pa}$ Yayıncllik

Öncü, T. (2003). Torrance Yaratıcı Düşünme Testleri-Şekil Testi aracılığıyla 12-14 yaşları arasındaki çocukların yaratıcılık düzeylerinin yaş ve cinsiyete göre karşılaştırılması, Ankara Üniversitesi Dil ve Tarih Coğrafya Fakültesi Dergisi, 43(1), 98-124. 
Özçelik, A., ve Akgündüz, D. (2018). Üstün/özel yetenekli öğrenciler için okul dişı STEM eğitiminin değerlendirilmesi. Trakya Üniversitesi Eğitim Fakültesi Dergisi, 8(2), 334-351.

Özerbaş, M. A. (2011). Yaratıcı düşünme öğrenme ortamının akademik başarı ve bilgilerin kalıcılığa etkisi. Gari Eğitim Fakültesi Dergisi, 31(3), 675-705.

Polat, Ö., ve Bardak, M. (2019). Türkiye'de erken çocukluk döneminde STEM yaklaşımı. International Journal of Social Science Research, 8(2), 18-41.

PWC Türkiye TÜSİAD. (2017). 2023'e Doğru Türkiye'de STEM Gereksinimi Raporu. İstanbul, Türkiye, $28 \mathrm{s.}$

Roberts, L. (2003). Creativity. Tech Directions, 63(3), 12

Siew, M., Amir, N., and Chong, L. (2015). The perceptions of pre-service and in-service teachers regarding a project-based. STEM approach to teaching science. Springer Plus, 4(3), 1-20.

Soylu, S.(2016). STEM education in early childhood in Turkey. Journal of Educational and Instructional Studies in the World, 6(1), 38-47.

Tank, K. M., Moore, T .J., Dorie, B. L., Gajdzik, E., Sanger, M. T., Rynearson, A. M., and Mann, E. F. (2018). Engineering in early elementary classrooms through the integration of high-quality literature, design, and STEM context. Early engineering learning. Netherlands: Springer.

Tippett, D., and Milford, M. (2017). Anaokulu öncesi bir sınıftan bulgular: erken çocukluk eğitiminde STEM için vaka oluşturma. Uluslararası Bilim ve Matematik Eğitimi Dergisi, 15, 6786.

Torrance, E. P. (1965). Rewarding Creative Behavwor. Englewood Cliffs, NJ: Prentice-Hall Uğraş, M. (2017). Okul öncesi öğretmenlerinin STEM uygulamalarına yönelik görüşleri. The Journal of New Trends in Educational Science, 1(1), 39-54.

Torrance, E.P., and Ball, O.E. (1984). Torrance tests of creative thinking. streamlined (revised) manual. Figural Tests A-B. Scholastic Testing Service. Illinois

Uğraş, M. (2017). Okul öncesi öğretmenlerinin STEM uygulamalarına yönelik görüşleri. The Journal of New Trends in Educational Science, 1(1), 39-54.

Ülger, K. (2014). The investigation of the students' creative thinking development. Education and Science, 39(175), 275-284.

Yıldırım, A. (2014). Okul öncesinde yaratıc problem çöæme etkinliklerinin yaratıcliğga etkisi (5 yas örneği). Doktora Tezi, Hacettepe Üniversitesi Sosyal Bilimler Enstitüsü, Ankara

Yıldırım, B., ve Altun, Y. (2014). STEM eğitimi üzerine derleme çalışması: Fen bilimleri alanında örnek ders uygulanmaları. International of Education Research, 4(3), 239248.

Yıldırım, B., ve Türk, C. (2017). Sınıf öğretmeni adaylarının STEM eğitimine yönelik görüşleri: uygulamalı bir çalışma. Trakeya Üniversitesi Eğitim Fakültesi Dergisi, 8(2), 195-213

Zan, B., and Geiken, R. (2010). Ramps and Pathways: Developmentally Appropriate. Intellectually Rigorous and Fun Physical Science, 65(1), 12-12.

Wendell, K.B. (2008). The theoretical and empirical basis for design-based science instruction for children. Tufts University Qualifying Paper, 3(2), 92- 136. 